\title{
SISTEM PEMBAYARAN DANA PENSIUN NASABAH PADA PT BANK BTPN PURNA BAKTI KC MATARAM
}

\author{
Wina Hartini ${ }^{1}$, Anom Ismail ${ }^{2}$ \\ ASM Mataram ${ }^{1,2)}$ \\ anom.ismail.mpd@gmail.com
}

\begin{abstract}
Abstrak - Bank Tabungan Pensiunan Nasional (BTPN) sebagai lembaga bank devisa yang memfokuskan diri untuk melayani masyarakat yang berpendapatan rendah yang terdiri dari pensiunan, pelaku usaha mikro kecil dan menengah, serta komunitas prasejahtera produktif. BTPN meluncurkan sebuah aplikasi yang berbasis Androit maupun Iphone Operating System (IOS) untuk mempermudah melakukan transaksi perbankan seperti, simpanan, tarik tunai, transfer dana, pembayaran tagihan dan pengajuan permohonan kredit mikro, sehingga sistem pembayaran dalam transaksi ekonomi sangat dibutuhkan dan mengalami kemajuan yang pesat seiring dengan perkembangan teknologi yang canggih. Dalam pembayaran pensiun secara konvensional Bank BTPN terlebih dahulu melakukan penerimaan calon nasabah pensiun. Calon nasabah pensiun harus memenuhi syarat administratif. Calon nasabah yang telah memenuhi syarat tersebut berhak menjadi nasabah BTPN. Nasabah BTPN mendapat nomor rekening serta buku tabungan untuk dapat mengambil gaji pensiun setiap bulannya. Nasabah akan dilayani oleh bagian teller dalam pembayaran dana pensiun. Hasil penelitian ini diharapkan dapat menjadi bagian masukan bagi PT Bank BTPN Purna Bakti KC Mataram dalam menentukan langkah-langakah kebijakan sebagai upaya meningkatkan kualitas dan produktifitas.
\end{abstract}

Kata Kunci : Pembayaran, Pensiun, Nasabah, Bank BTPN

\section{Latar Belakang}

Bank Tabungan Pensiunan Nasional (BTPN) sebagai lembaga bank devisa yang memfokuskan diri untuk melayani masyarakat yang berpendapatan rendah yang terdiri dari pensiunan, pelaku usaha mikro kecil dan menengah, serta komunitas prasejahtera produktif. BTPN meluncurkan sebuah aplikasi yang berbasis Androit maupun Iphone Operating System (IOS) untuk mempermudah melakukan transaksi perbankan seperti, simpanan, tarik tunai, transfer dana, pembayaran tagihan dan pengajuan permohonan kredit mikro, sehingga sistem pembayaran dalam transaksi ekonomi sangat dibutuhkan dan mengalami kemajuan yang pesat seiring dengan perkembangan teknologi yang canggih. Kemajuan teknologi dalam sistem pembayaran telah menggantikan peranan uang (currency) yang dikenal masyarakat sebagai alat pembayaran pada umumnya ke dalam bentuk pembayaran nontunai yang lebih efektif dan efisien.

Hal ini didukung dengan semakin banyaknya perusahaan-perusahaan ataupun pusat perbelanjaan di Indonesia yang menerima transaksi pembayaran dengan menggunakan sistem pembayaran nontunai. Beberapa pembayaran nontunai yang berkembang di masyarakat sekarang ini, selain yang umum diketahui seperti kartu kredit, kartu debit, kartu ATM, kartu prabayar dan mobile banking. Sehingga lebih Cepat, aman, nyaman, mudah dan efisien dalam bertransaksi merupakan alasan masyarakat Indonesia memiliki respon yang besar terhadap sistem pembayaran non tunai, dan sistem pembayaran non tunai ini telah dikembangkan oleh pihak bank maupun non bank sebagai lembaga penyelenggaraan sistem pembayaran di Indonesia.
Kelembagaan dalam sistem pembayaran meliputi berbagai lembaga yang secara langsung maupun tidak langsung berperan dalam penyelenggaraan sistem pembayaran. Secara umum lembaga-lembaga yang terlibat dalam sistem pembayaran meliputi antara lain bank sentral, bank-bank dan lembaga kliring, pasar modal, penyedia jasa jaringan komunikasi, penerbit kartu kredit, dan lain-lain. Masing-masing lembaga tersebut mempunyai peran dan tanggung jawab yang berbeda dalam sistem pembayaran (Aulia Pohan, 2011:103).

Sistem pembayaran memiliki implikasi yang sangat kuat terhadap stabilitas sistem keuangan bahkan terhadap perekonomian suatu bangsa. Sistem pembayaran yang dapat memenuhi semua prinsip yang dipersyaratkan, yakni dapat meminimalkan risiko yang dapat terjadi, sangat efisien, memiliki kesetaraan akses dan melindungi konsumen, akan menjadi modal bagi stabilitas sistem keuangan. Sebaliknya sistem pembayaran yang tidak mampu meminimalkan risiko akan menjadi sumber instabilitas keuangan.

Munculnya kata sistem pembayaran di Bank Indonesia kala itu berasal dari kegiatan untuk meningkatkan efektivitas organisasi internal di Bank Indonesia. Kegiatan ini bertujuan agar Bank Indonesia dapat melaksanakan tugas yang betulbetul fokus sesuai mandat yang diembannya (Aulia Pohan, 2011:4).

Hasil penelitian ini diharapkan dapat menjadi bagian masukan bagi PT Bank BTPN Purna Bakti KC Mataram dalam menentukan langkah-langakah kebijakan sebagai upaya meningkatkan kualitas dan produktifitas. 


\section{Kajian Pustaka}

\section{a. Pengertian Sistem}

Kata sistem menurut kamus besar Bahasa Indonesia adalah sekelompok bagian-bagian yang bekerja bersama-sama untuk melakukan sesuatu maksud. Atau bisa juga diartikan sebagai cara atau metode yang teratur untuk melakukan sesuatu. (Aulia Pohan, 2011:70).

Sistem adalah serangkaian kegiatan dalam prosedur-prosedur atau elemen-elemen yang saling berkaitan atau saling berhubungan antara satu dengan yang lainnya dan tidak bisa di pisahkan. (Basuki, 2011:7 dalam Aprida, 2011:8).

Sistem adalah suatu kesatuan yang terdiri dari dua atau lebih komponen atau subsistem yang berinteraksi untuk mencapai suatu tujuan. Suatu sistem dapat terdiri dari sistem-sistem bagian (subsystem). (Rochaety, DKK, 2013:3).

\section{b. Pengertian Pembayaran}

Diartikan sebagai perpindahan nilai antara dua belah pihak. Secara sederhana, kedua belah pihak yang dimaksud adalah pihak pembeli dan pihak penjual. Jadi pada saat bersamaan terjadi perpindahan barang dan jasa. Dalam pengertian ini, maka dalam setiap kegiatan ekonomi, dimana terjadinya perpindahan barang dan jasa, pasti melibatkan apa yang disebut dengan proses pembayaran. (Aulia Pohan, 2011:70)

\section{c. Pengertian Dana Pensiun}

Menurut undang-undang Nomor 11 tahun 1992 Dana pensiun adalah badan hukum yang mengelola dan menjalankan program yang menjanjikan manfaat pensiun. Dengan demikian, jelas bahwa yang mengelola dana pensiun adalah perusahaan yang memiliki badan hukum seperti bank umum dan asuransi jiwa. (Kasmir, 2014:287)

Dana pensiun adalah sekumpulan aset yang dikelola dan dijalankan oleh suatu lembaga untuk menghasilkan suatu manfaat pensiun, yaitu suatu pembayaran berkala yang dibayarkan kepada peserta pada saat dan dengan cara yang ditetapkan dalam ketentuan yang menjadi dasar penyelenggaraan program pensiun. Program pensiun ini dimaksudkan untuk memberi kesejahteraan kepada karyawan suatu perusahaan terutama karyawan yang mencapai usia pensiun sesuai perjanjian, artinya dana pensiun dikelola oleh lembaga atau badan hukum dan memungut dana dari pendapatan para karyawan suatu perusahaan kemudian membayarkan kembali dana tersebut dalam bentuk manfaat pensiun setelah jangka waktu tertentu sesuai dengan perjanjian. (http://www.pustakauinib.ac.id/pdf)

\section{d. Pengertian Pensiun}

Pensiun adalah hak seseorang untuk memperoleh penghasilan setelah bekerja sekian tahun dan sudah memasuki usia pensiun atau ada sebab-sebab lain sesuai dengan perjanjian yang telah ditetapkan. (Kasmir, 2014:287).

Berdasarkan undang-undang No.43 tahun 1999 pasal 10, "pensiun adalah jaminan hari tua dan sebagai balas jasa terhadap pegawai negeri yang telah bertahun-tahun mengabdikan dirinya kepada Negara. Menurut kamus besar bahasa Indonesia, pensiun adalah status seseorang yang telah berakhir masa tugasnya di instansi di tempat ia bekerja sebelumnya, biasanya adalah instansi pemerintah atau orang tersebut bekerja sebagai pegawai negeri. (http://www.pustakauinib.ac.id/pdf)

\section{e. Pengertian Bank}

Menurut undang-undang RI Nomor 10 Tahun 1998 tanggal 10 November 1998 tentang perbankan, yang dimaksud dengan BANK adalah badan usaha yang menghimpun dana dari masyarakat dalam bentuk simpanan dan menyalurkannya kepada masyarakat dalam bentuk kredit dan atau bentuk-bentuk lainnya dalam rangka meningkatkan taraf hidup rakyat banyak. (Kasmir,2014:24).

\section{Perancangan Sistem}

\section{a. Sekilas Tentang PT Bank BTPN Purna} Bakti KC Mataram

PT Bank BTPN Purna Bakti KC Mataram berdiri pada tanggal 01 Juni 2010 di Jalan Pejanggik No. 86 Mataram. Aktivitas utama Bank BTPN adalah tetap mengkhususkan kepada pelayanan bagi para pensiunan dan pegawai aktif, karena target market Bank BTPN adalah Para Pensiunan. Semakin hari Bank BTPN mulai menunjukkan perkembangannya yang kemudian membuat segmen Usaha dan Mikro keci dikelola PT Bank BTPN Mitra Usaha, Bisnis Syariah Dikelola PT Bank BTPN Syariah dan pengelolaan dalam segmen Usaha Bisnis Pensiunan oleh PT Bank BTPN Purna Bakti.

BTPN telah menempuh perjalanan panjang sejak didirikan di Bandung, Jawa Barat pada 1958 sebagai Bank Pegawai Pensiunan Militer (Bapemil) hingga berubah nama pada 1986 menjadi Bank Tabungan Pensiunan Nasional. BTPN mulai tercatat di Bursa Efek Indonesia pada 2008. Selanjutnya BTPN berkembang secara berkelanjutan dengan melahirkan berbagai inovasi bisnis yang melengkapi portofolio layanan perbankan pensiun yang telah dirintis sejak 1958.

\section{b. Uraian Kegiatan Selama melakukan Penelitian}

1. Menulis nomor Customer Information File (CIF) nasabah pada paper craft. Pada kegiatan menulis nomor CIF 
nasabah dan nama nasabah. Kegiatan ini dilakukan pada saat ada formulir baru nasabah dan pada saat ada nasabah baru.

2. Memasukkan formulir nasabah ke ruang Know Your Customer (KYC). Selanjutnya memasukkan formulir yang sudah diberi nomor CIF dan nama nasabah untuk di gantung sesuai urutan abjad dan angka.

3. Menggantung formulir nasabah sesuai urutan abjad pada nomor Customer Information File (CIF). Pada kegitan menggantung formulir nasbah pada tempat yang sudah disediakan (Rak bertingkat).

4. Mengurutkan laporan teller per bulan. Pada kegiatan ini mengurutkan laporan keuangan teller per bulan dari bulan Januari sampai bulan Desember tahun 2017 yang lalu.

5. Pengepakan dokumen laporan teller dan dokumen pembayaran pensiun. Kegiatan ini berupa memasukkan dokumen laporan teller ke karduskardus sesuai bulan dan memberikan nama di luar kardus tersebut agar saat dicari bisa langsung ditemukkan, dan juga memasukkan dokumen pembayaran pensiun.

6. Mengarsip formulir perubahan dana. Mengarsip formulir perubahan dana nasabah untuk di masukkan ke ruang $\mathrm{KYC}$, dengan menggunakan sistem abjad dan angka.

7. Memasukkan data ke amplop besar "data Kartu Contoh Tanda Tangan (KCTT) aktif dan Contoh Kartu Tanda Tangan (KCTT) close. Pada kegiatan memilih Kartu contoh tanda tangan (KCTT) yang masih aktif untuk di masukkan ke dalam amplop besar, dan untuk Kartu contoh tanda tangan (KCTT) close sudah tidak diperlukan lagi.

8. Merekapitulasi daftar tagihan pinjaman dan merekapitulasi bukti penerimaan angsuran. Disini merekapitulasi tagihan pinjaman dan bukti penerimaan angsuran sesuai instansi yang menerima tagihan pinjaman dan yang menerima angsuran.

9. Menulis slip setoran. Menulis slip setoran dan memasukkan nomor urutan slip ke dalam buku slip setoran.

10. Merekapitulasi penyaluran dana pensiun per kordinator mitra bayar dan merekapitulasi daftar penerima pensiun yang tidak berhak. Memasukkan data penyalurandana pensiun dan penerima pensiun yang tidak berhak ke komputer

11. Merekapitulasi data realisasi pembayaran pensiun dan saldo uang pensiun ke computer. Memasukkan data realisasi pembayaran dana pensiun dan saldo uang pensiun yang sesuai dengan yang ada di formulir.

12. Memprint out bilyet giro dan cek. Pada kegiatan print out bilyet giro dan cek yang merupakan salah satu alat pembayaran yang digunakan di perusahaan PT Bank BTPN Purna Bakti KC Mataram.

\section{Implementasi Sistem dan Hasil}

\section{a. Sistem Pembayaran Dana Pensiun Nasabah Pada PT Bank BTPN Purna Bakti KC Mataram}

Adapun sistem pembayaran dana pensiun nasabah pada PT Bank BTPN Purna Bakti KC Mataram Adalah System Application and Product (SAP) adalah aplikasi transaksi pembayaran angsuran pensiun atau jaminan hari tua dan juga merupakan suatu software yang dikembangkan untuk mendukung suatu organisasi dalam menjalankan kegiatan operasionalnya secara efisien dan efektif. SAP merupakan software Enterprise Resources Planning (ERP), yaitu suatu tools IT dan manajemen untuk membatu perusahaan merencanakan dan melakukan berbagai aktivitas sehari-hari yang berhubungan dengan pengelolaan sumber daya sebuah perusahaan, seperti dana, manusia dan mesin.

System application and product memberikan manfaat bagi Bank, diantaranya :

1) Mempermudah Bank dalam tahapan proses pembayaran dana pensiun pada nasabah sehingga lebih cepat, efisien dan efektif.

2) Meningkatkan fungsi monitoring dan control di masing-masing bagian sistem. Maksudnya adalah melakukan pengawasan terhadap bagian-bagian sistem apakah bekerja dengan baik. Dengan monitoring diharapkan jika terjadi permasalahan pada jaringan dapat di perbaiki dengan cepat dan mudah oleh administrator.

3) Mengurangi human errors.

4) SAP terdiri dari sejumlah modul aplikasi yang mempunyai kemampuan mendukung semua transaksi yang perlu dilakukan suatu perusahaan dan tiap aplikasi bekerja secara berkaitan satu dengan yang lainnya. SAP dilengkapi dengan modul besar yaitu
a) Human Resource (mengurus segala hal berkaitan dengan personalia, Mengintegrasikan proses-proses HR mulai dari aplikasi pendaftaran, administrasi 
pegawai, management waktu, pembiayaan, sampai ke proses pembayaran gaji).

b) Modul Finace (mengurus segala berkaitan dengan keuangan perusahaan)

c) Logistic (mengurus segala hal berkaitan dengan sumber daya yang berbentuk barang baik asset bergerak ataupun tetap)

5) SAP juga dapat melakukan modifikasi pada aplikasi ataupun program yang dibangun menggunakan bahasa pemograman SAP yang biasa dikenal ABAP (Advance Business Aplication Programming)

b. Alur Sistem Pembayaran Dana Pensiun Nasabah Pada PT Bank BTPN Purna Bakti KC Mataram.

Adapun alur dari sistem pembayaran dana pension nasabah yaitu pertama Nasabah yang akan menerima dana pensiun datang langsung ke kantor Bank BTPN Purna Bakti KC Mataram untuk mengambil gaji atau dana pensiunnya. Kedua Nasabah yang akan mengambil dana pensiun mengisi slip penarikan yang sudah disediakan Bank yang berada di depan loket teller. Ketiga Nasabah menuju loket teller dengan sistem antrian, teller memeriksa kelengkapan pengisian slip penarikan.

Pada gambar 1 dibawah ini menjelaskan tentang alur pada sistem pembayaran dana pensiun nasabah.

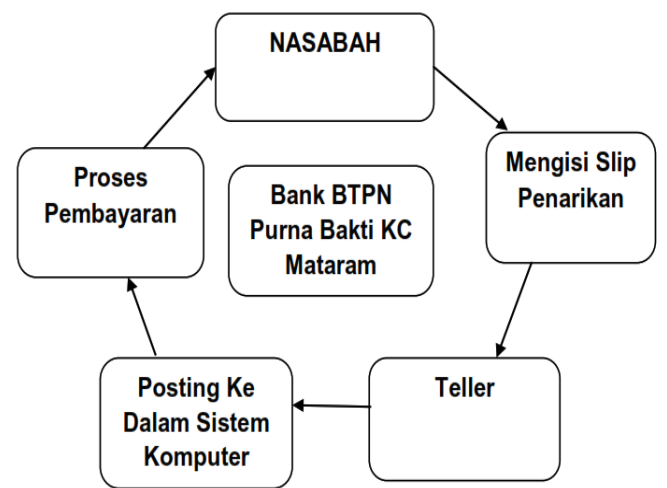

Gambar 1. Alur Sistem Pembayaran Dana Pensiun

Setelah memeriksa kelengkapan pengsisian slip penarikan, selanjutnya teller melakukan login kedalam sistem komputer dengan memasukan user dan password sesuai user dan passwordnya masing-masing, karena di Bank BTPN Purna Bakti KC Mataram setiap karyawan mempunyai user dan password masing-masing. Setelah itu login untuk melakukan langkah selanjutnya, jika user name dan password sudah di vertifikasi sistem dan benar, maka user akan masuk ketampilan halaman yaitu untuk mengecek data nasabah.

Halaman login ke SAP dapat dilihat pada gambar 2 dibawah ini.

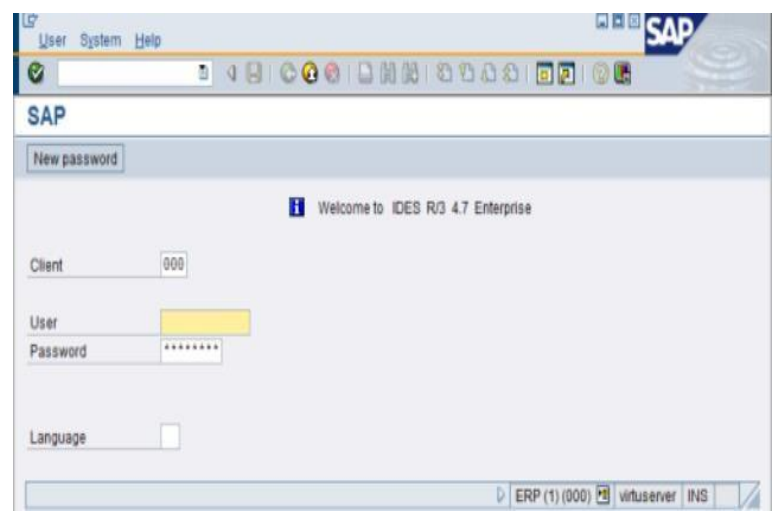

Gambar 2. Halaman Login SAP

Setelah masuk ke dalam sistem, teller melakukan posting kedalam sistem komputer sesuai dengan menu yang ada pada user. Teller mencocokkan data yang ada pada komputer dengan data tabungan uang pensiun dan karip yang bersangkutan, dengan mencocokkan nomor CIF, nomor rekening dan nama nasabah.

Halaman data nasabah dapat dilihat pada gambar 3 dibawah ini.

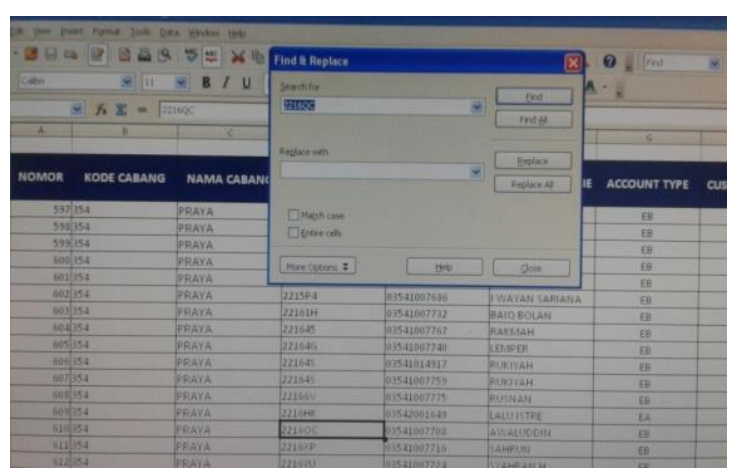

Gambar 3. Halaman Pencocokan Data Nasabah.

Setelah data nasabah yang ada pada sistem komputer benar maka teller melakukan proses pembayaran dengan menerima, memeriksa, dan mencocokkan buku tabungan uang pensiun dan kartu identitas pensiun (karip) dari nasabah pensiun. Teller melakukan pembayaran tabungan uang pensiun yang bersangkutan dan cetak buku tabungan uang pensiun. Berdasarkan slip penarikan, teller menyiapkan uang tunai sesuai dengan jumlah yang harus dibayarkan.

Teller menghitung uang secara terperinci dengan menggunakan bantuan mesin penghitung uang dan menghitung kembali secara manual sebelum diserahkan kepada nasabah yang bersangkutan. Teller juga meminta nasabah menghitung uang dan menandatangani slip penarikan sebagai tanda terima. Menyerahkan slip penarikan, buku tabungan pensiun dan karip kepada nasabah. 


\section{c. Dokumen yang digunakan dalam pembayaran dana pensiun nasabah di PT Bank BTPN Purna Bakti KC Mataram}

1) Surat keputusan pensiun.

Dokumen ini merupakan surat keputusan pemberhentian kerja secara hormat untuk pegawai.

2) Surat pernyataan pembayaran pensiun melalui rekening.

Dokumen ini merupakan pernyataan nasabah bahwa pembayaran pensiunan dilakukan melalui BTPN KC Mataram

3) Foto Copy Kartu Identitas Pensiun. Dokumen ini berupa kartu identitas diri berupa KTP atau passport yang sesuai dengan aslinya. Untuk WNA harus disertai dengan Kartu Izin Menetap Sementara (KIMS).

4) Foto berwarna

Foto berwarna digunakan berukuran $3 \times 4$ $\mathrm{cm}$. pas foto digunakan sebagai visualisasi wajah nasabah. Foto ini diserahkan sebagai kelengkapan berkas saat melakukan pembukaan rekening tabungan.

5) Formulir aplikasi pembukaan rekening tabungan.

Jika nasabah belum memiliki nomor rekening di BTPN, maka disarankan untuk membuka rekening baru di BTPN. Formulir ini berisi data diri nasabah seperti nama, alamat, tempat tanggal lahir, nama ibu, nomor kartu identitas, dan tanda tangan.

6) Buku tabungan

Setelah nasabah mengisi formulir pembukaan rekening baru, nasabah akan diberikan buku tabungan yang berisi nama, tanda tangan, serta nomor rekening. Dokumen ini dipegang oleh nasabah berfungsi sebagai informasi saldo, penarikan, penyetoran dan pemindah bukuaan serta sebagai pembebanan yang dilakukan oleh pihak bank pada suatu tanggal tertentu.

7) Kartu contoh tanda tangan

Kartu yag ditandatangani oleh nasabah pada saat membuka rekening tabungan. Dokumen ini digunakan untuk scanning pada buku tabungan. Selanjutnya digunakan untuk mencocokan tanda tangan nasabah pada buku tabungan serta slip penarikan. Duplikat kartu disimpan dikantor BTPN KC Mataram

8) Slip penarikan tabungan

Dokumen untuk menarik sejumlah uang dari rekening tabungan nasabah. Di dalam slip ini dituliskan nama, nomor rekening, jumlah yang akan ditarik dan tanda tangan nasabah. Sebagai bukti penarikan tabungan nasabah.

\section{Kesimpulan}

Sistem pembayaran dana pensiun pada PT Bank BTPN Purna Bakti KC Mataram menerapkan System Application Product untuk mendukung suatu organisasi menjalankan kegiatan operasional secara lebih efisien dan efektif dan membatu perusahaan merencanakan dan melakukan berbagai aktivitas sehari-hari yang berhubungan dengan pengelolaan sumber daya sebuah perusahaan, seperti dana, manusia dan mesin. Dalam pembayaran pensiun secara konvensional Bank BTPN terlebih dahulu melakukan penerimaan calon nasabah pensiun. Calon nasabah pensiun harus memenuhi syarat administratif. Calon nasabah yang telah memenuhi syarat tersebut berhak menjadi nasabah BTPN. Nasabah BTPN mendapat nomor rekening serta buku tabungan untuk dapat mengambil gaji pensiun setiap bulannya. Nasabah akan dilayani oleh bagian teller dalam pembayaran dana pensiun.

\section{Daftar Pustaka}

Kasmir, Dr. 2014. Bank dan Lembaga Keuangan Lainnya, Penerbit Rajawali Pers

Margono, s. Dr. 2014. Metodologi Penelitian Pendidikan, Penerbit Rineka Cipta.

Pohan, Aulia. November. 2011 Sistem Pembayaran, Penerbit Rajawali Pers

Rochaeti, DKK. 2013. Sistem Informasi Manajemen, Jakarta: Penerbit Mitra Wacana Media

http://www.pustakauinib.ac.id/repository/file/original

https://perpuskampus.com/pengertian-dan-jenisnasabah

http://www.bi.go.id/id/iek/alatpembayaran/contents/d efault.aspx 